\title{
PENGADILAN INTERNASIONAL DALAM MEMBERANTAS TINDAK PIDANA TERORISME: TANTANGAN HUKUM DAN POLITIK
}

\author{
Syarif Saddam Rivanie \\ Dosen Fakultas Hukum, Universitas Hasanuddin, Makassar \\ Email Korespondensi: ivanparawansa@gmail.com
}

Tanggal Penyerahan: 01 Agustus 2020

Tanggal Publikasi: 28 September 2020

Abstrak. Penelitian ini bertujuan untuk mengetahui dan menganalisis yurisdiksi dan pengadilan internasional tindak pidana terorisme, serta implikasi antar negara terkait aspek hukum dan politik. Tipe penelitian yang digunakan adalah penelitian hukum normatif (legal study research). Adapun bahan hukum yang digunakan yaitu bahan hukum primer dan badan hukum sekunder. Teknik pengumpulan bahan hukum dalam penelitian ini adalah dengan cara menganalisis serta melakukan penelusuran yang mendalam dan secara sistematik terhadap peraturan perundangundangan dan referensi-referensi hukum yang dipandang erat korelasinya dengan objek yang dikaji. Lebih lanjut, analisis bahan hukum dilakukan dengan cara inventarisasi kaidah-kaidah hukum dalam peraturan perundang-undangan, melakukan kategorisasi sesuai dengan sifatnya, serta mendeskripsikan dengan memberi makna hukum. Hasil penelitian menunjukkan bahwa yurisdiksi dan pengadilan internasional dapat didasarkan pada prinsip keutamaan (menjalankan yurisdiksi hingga ke pengadilan) atau prinsip komplementaritas atau saling melengkapi (melimpahkan yurisdiksi kepada negara asal si pelaku). Selanjutnya, pengadilan internasional akan memiliki spesifikasi temporal dan geografis yang jelas dan terbatas, dan apabila penyelenggaraannya telah teraktualisasi dengan baik, maka pengadilan tersebut akan dibubarkan. Adapun beberapa anggota konvensi internasional menekankan bahwa definisi terkait tindak pidana terorisme harus jelas, khususnya dalam membedakan tindak pidana terorisme dengan perjuangan sah rakyat dalam menjalankan hak mereka untuk menentukan nasib sendiri dari pendudukan asing atau dominasi kolonial. Dengan dasar kesimpulan tersebut, untuk menghindari kontroversi politik, khususnya perihal konsep terorisme negara, maka disarankan agar memberikan definisi yang tepat atas tindak pidana terorisme dan diadopsi dalam yurisdiksi TIT untuk meminimalisir tindakan terorisme yang dapat terulang di masa yang akan datang.

Kata Kunci:

Pengadilan Internasional; Politik;

Tindak Pidana Terorisme; Yurisdiksi.

Artikel dengan akses terbuka di bawah lisensi CC BY SA-4.0 


\section{PENDAHULUAN}

Pengadilan Internasional tentang Kejahatan Teroris Internasional (International Tribunal on Crimes of International Terrorist) berakar pada Konvensi Pencegahan dan Penghukuman Terorisme (Convention for the Prevention and Punishment of Terrorism) yang diselenggarakan oleh Liga Bangsa-Bangsa (League of Nations) pada tanggal 1-16 November 1937, di Geneva (Muh. Khamdan, 2016). Akan tetapi berbeda dengan sebagaimana proyek pencegahan lainnya, ancaman terorisme selalu berhasil bertahan sesuai dengan perkembangan dunia global (Debora Sanur Lindawaty, 2016). Olehnya itu, Perkumpulan Negara Dunia tidak henti-hentinya melakukan sebuah pertemuan dan kesepakatan Internasional guna menyikapi persoalan terorisme, antara lain yaitu:

1. League of Nations Tahun 1937 tentang Convention for the Prevention and Punishment of Terrorism. (Disahkan pada tanggal 16 November 1937, di Geneva);

2. United Nations Tahun 1997 tentang International Convention for the Suppression of Terrorist Bombings. (Disahkan pada tanggal 12 Januari 1998, di New York);

3. United Nations Tahun 1999 tentang International Convention for the Suppression of the Financing of Terrorism. (Disahkan pada tanggal 10 Januari 2000, di New York);

4. United Nations Tahun 2005 tentang International Convention for the Suppression of Acts of Nuclear Terrorism. (Disahkan pada tanggal 14 September 2005, di New York);

5. Association of Southeast Asian Nations Tahun 2007 tentang Asean Convention on Counter Terrorism. (Disahkan pada tanggal 17 Januari 2007, di Filipina).

Dari serangkaian pertemuan dan kesepakatan Internasional di atas, Negara dimaksudkan untuk memperkuat supremasi hukum, dengan memperbaiki defisit legitimasi yang diciptakan oleh langkah-langkah yang diambil selama ingin menegaskan "perang melawan teror" atau "war of terror" (Ardli Johan Kusuma et al., 2019).

Dilain sisi, menurut Syarif Saddam Rivanie (2020) bahwa sekalipun menjadi perhatian internasional, tindak pidana terorisme merupakan salah satu bentuk dari kejahatan transnasional dan bukan merupakan bentuk kejahatan internasional. Hal ini didasarkan pada Pasal 5 ayat (1) Rome Statute of the International Criminal Court, mengatur bahwa Yurisdiksi Mahkamah terbatas pada kejahatan paling serius yang menyangkut masyarakat internasional secara keseluruhan. Mahkamah mempunyai yurisdiksi sesuai dengan Statuta berkenaan dengan kejahatan-kejahatan berikut:

(a) Kejahatan genosida;

(b) Kejahatan terhadap kemanusiaan;

(c) Kejahatan perang;

(d) Kejahatan agresi.

Sedangkan perihal kejahatan transnasional, sebagaimana berdasarkan United Nations Convention against Transnational Organized Crime, menguraikan bahwa:

"Sangat yakin bahwa Konvensi Perserikatan Bangsa-Bangsa melawan Kejahatan Terorganisir Transnasional akan menjadi alat yang efektif dan kerangka hukum yang diperlukan untuk kerjasama internasional dalam memerangi, antara lain, kegiatan kriminal seperti pencucian uang, korupsi, 
perdagangan gelap spesies flora dan fauna liar yang terancam punah, pelanggaran terhadap warisan budaya dan hubungan yang berkembang antara kejahatan transnasional terorganisir dan kejahatan teroris."

Selanjutnya, dibutuhkan ratifikasi oleh Negara-Negara dalam mengadopsi langkahlangkah yang diperlukan untuk memastikan supremasi hukum dalam memerangi ancaman ini (Umbu Lily Pakuwali, 2009).

Indonesia sebagai salah satu negara yang juga turut serta dalam pemberantasan tindak pidana terorisme telah melakukan beberapa ratifikasi terhadap pertemuan dan kesepakatan Internasional menjadi peraturan-perundang-undangan (Syarif Saddam Rivanie, 2020), antara lain yaitu:

1. Undang-Undang Republik Indonesia Nomor 6 Tahun 2006 tentang Pengesahan International Convention for the Suppression of the Financing of Terrorism, 1999 (Konvensi Internasional Pemberantasan Pendanaan Terorisme, 1999);

2. Undang-Undang Republik Indonesia Nomor 5 Tahun 2006 tentang Pengesahan International Conventional for the Suppression of Terrorist Bombings, 1997 (Konvensi Internasional Pemberantasan Pengeboman oleh Teroris, 1997);

3. Peraturan Presiden Republik Indonesia Nomor 3 Tahun 2010 tentang Pengesahan Memorandum Saling Pengertian antara Pemerintah Republik Indonesia dan Pemerintah Federasi Rusia tentang Kerja Sama di Bidang Pemberantasan Terorisme (Memorandum of Understanding Between the Government of the Republic of Indonesia and the Government of the Russian Federation on Cooperation in Combating Terrorism);

4. Undang-Undang Republik Indonesia Nomor 5 Tahun 2012 tentang Pengesahan Asean Convention on Counter Terrorism (Konvensi Asean Mengenai Pemberantasan Terorisme);

5. Undang-Undang Republik Indonesia Nomor 10 Tahun 2014 tentang Pengesahan International Convention for the Suppression of Acts of Nuclear Terrorism (Konvensi Internasional Penanggulangan Tindakan Terorisme Nuklir).

Di sisi lain, gagasan pembentukan yurisdiksi internasional yang kompeten tentang isu terorisme juga didorong oleh Spanyol dan Belanda melalui Stemming the Flow of Foreign Terrorist Fighters yang diselenggarakan oleh United Nations Security Council Counter-Terrorism Committee, pada tanggal 28 Juli 2015, di Madrid (Aryuni Yuliantiningsih, 2013), yaitu bahwa:

"Reaffirms that Member States must ensure that any measures taken to counter terrorism comply with all their obligations under international law, in particular international human rights law, international refugee law, and international humanitarian law (Menegaskan kembali bahwa Negara Anggota harus memastikan bahwa setiap tindakan yang diambil untuk melawan terorisme mematuhi semua kewajiban mereka berdasarkan hukum internasional, khususnya hukum hak asasi manusia internasional, hukum pengungsi internasional, dan hukum humaniter internasional)"

Berdasarkan uraian di atas, maka tujuan penelitian ini adalah untuk mengetahui dan menganalisis yurisdiksi dan pengadilan internasional tindak pidana terorisme, serta implikasi antar negara terkait aspek hukum dan politik. 


\section{METODE PENELITIAN}

Tipe penelitian ini adalah penelitian hukum normatif (legal study research) dengan pendekatan perundang-undangan (statute approach) yang bertujuan untuk mempelajari penerapan norma atau kaidah hukum dalam praktik hukum (Said Sampara \& La Ode Husen, 2016). Jenis dan sumber bahan hukum penelitian ini, dikelompokkan ke dalam beberapa jenis, sebagai berikut (Peter Mahmud Marzuki, 2016):

1. Bahan hukum primer, adalah data yang bersumber dari asas-asas hukum, kaidahkaidah hukum dan peraturan perundang-undangan.

2. Bahan hukum sekunder, adalah bahan hukum pendukung dan pelengkap dari bahan hukum primer, yang bersumber dari referensi-referensi hukum, berupa Buku-buku teks hukum dan hasil penelitian dan Jurnal-jurnal Ilmiah.

Teknik pengumpulan bahan hukum dalam penelitian ini adalah dengan cara menganalisis serta melakukan penelusuran yang mendalam dan secara sistematik terhadap peraturan perundang-undangan dan referensi-referensi hukum yang dipandang erat korelasinya dengan objek yang dikaji. Lebih lanjut, analisis bahan hukum dilakukan dengan cara inventarisasi kaidah-kaidah hukum dalam peraturan perundang-undangan, melakukan kategorisasi sesuai dengan sifatnya, serta mendeskripsikan dengan memberi makna hukum (Nurul Qamar \& Farah Syah Rezah, 2020).

\section{HASIL DAN PEMBAHASAN}

\section{A. Esensi Tindak Pidana Terorisme}

Terorisme bukan suatu hal yang mudah untuk didefinisikan, sehingga M. Cherif Bassiouni (1974) mengusulkan tiga pilihan metodologis dalam memahaminya, antara lain yaitu:

1. Definisi umum;

2. Pilihan-pilihan tindakan konkret yang dirumuskan sedemikian rupa sehingga mengandung maksud khusus dari perilaku; serta

3. Formula campuran yang menggabungkan definisi umum dengan beberapa aplikasi khusus konten ilustrasi yang menunjukkan perilaku terlarang.

Dilain sisi, Asas legalitas merupakan acuan prinsip dasar hukum pidana. Asas legalitas pertama kali dikemukakan oleh Paul Johann Anselm Ritter von Feuerbach, seorang ahli hukum berkebangsaan Jerman. Menurut Feuerbach, asas legalitas dapat diuraikan menjadi 3 (tiga) konsep, yaitu (Imam Budi Santoso \& Taun Taun, 2018):

"Pertama, nulla poena sine lege, yang artinya setiap penjatuhan hukuman haruslah didasarkan pada suatu undang-undang pidana; kedua, nulla poena sine crimine, yang artinya setiap penjatuhan hukuman hanyalah dapat dilakukan apabila perbuatan yang bersangkutan telah diancam dengan suatu hukuman oleh undang-undang; serta ketiga, nulla crimen sine poena legali, yang artinya suatu perbuatan yang diancam dengan hukuman oleh undang-undang itu apabila dilanggar berakibat dijatuhkannya hukuman seperti yang diancamkan oleh undang-undang terhadap pelanggarnya." 
Para promotor Tribunal on Crimes of International Terrorist (TIT), sepenuhnya menyadari hambatan dalam menentukan kejahatan terorisme sebagai subjek yurisdiksi pengadilan internasional di masa depan (Bogdan Aurescu \& Ion Gâlea, 2015). Olehnya itu, definisi yang diajukan oleh promotor TIT terdiri dari elemen, antara lain:

1. Tindakan yang dimuat dalam konvensi anti-terorisme Perserikatan BangsaBangsa; serta

2. Definisi umum berdasarkan unsur-unsur yang diakui oleh hukum dan yurisprudensi kebiasaan internasional.

Definisi dua tingkatyang diajukan untuk TIT serupa dengan formula campuran yang bertentangan dengan prinsip hukum pidana. Definisi umum yang dipertahankan (berisi mens rea) dan daftar tindakan terorisme yang tidak hanya ilustrasi (actus reus), tetapi terbatas pada tindakan yang dimaksud dalam konvensi Perserikatan Bangsa-Bangsa (PBB). Awalnya, Liga Bangsa-Bangsa menilai bahwa aturan hukum internasional yang berkaitan dengan tindak pidana terorisme tidak cukup tepat dan efisien untuk menjamin kerjasama internasional (Mamay Komariah, 2017). Untuk memperbaiki ketidakcukupan ini, diputuskan untuk membentuk Komite Internasional untuk Pemberantasan Terorisme atau Committee for the International Repression of Terrorism (CIRT), dengan salah satu tujuannya yaitu "merancang konvensi internasional untuk memastikan penindasan atas konspirasi atau kejahatan yang dilakukan dengan tujuan politik".

Lebih lanjut, keterhubungan antara mens rea dengan actus reus menghadirkan klasifikasi terkait TIT, antara lain yaitu:

1. Tindak pidana;

2. Diarahkan terhadap suatu Negara;

3. Tujuan atau sifatnya menyebabkan teror;

4. Menyebabkan provokasi terhadap pribadi, kelompok orang atau publik tertentu;

5. Memiliki jejaring internasional.

Dari klasifikasi terkait definisi di atas, Ben Saul (2005) mengindikasikan bahwa:

"Mens rea menghilangkan motif politik dan tujuan dari pembentukan CIRT, sehingga tindak pidana terorisme didefinisikan secara tautologis dengan mengacu pada ungkapan ambigu 'memprovokasi teror'. Selain itu, dalam actus reus hanya tindakan yang ditujukan terhadap negara yang dianggap teroris, sehingga tidak termasuk tindakan yang dilakukan terhadap individu."

Adapun TIT dapat diurai lebih lanjut dari sisi motif, dimana terorisme dapat dibedakan atas dua niatan (Robert Cryer, Darryl Robinson, \& Sergey Vasiliev, 2019), antara lain yaitu:

1. Niat umum, yaitu menyebarkan ketakutan di antara penduduk; dan

2. Niat khusus, yaitu memaksakan suatu negara atau organisasi internasional untuk melakukan atau tidak melakukan sesuatu.

Niat khusus di atas didasarkan pada tujuan politik atau ideologis, dimana kerap menimbulkan dua masalah (Rahmat Hi. Abdullah, 2015), antara lain yaitu: 
1. TIT belum dikonfigurasi dan diterima secara luas dan konsisten hingga mencapai tingkat hukum adat;

2. Tindak pidana teroris lebih dari sekedar niat, dalam hal ini dibedakan antara teroris yang mengejar tujuan politik dan yang mengejar tujuan pidana yang dalam waktu bersamaan ditampilkan sebagai agenda politik.

Dari uraian di atas dapat disimpulkan bahwa definisi TIT dari aspek mens rea, tidak menemukan konsensus yang cukup untuk memasukkan pengaruh konvensi internasional pada peraturan perundang-undangan. Hal ini dikarenakan alasan politik atau ideologis, dimana keberadaan TIT tetap harus mempertimbangkan kompleksitas dari tindak pidana teroris di suatu negara (Masdar Hilmy, 2015). Adapun definisi TIT dari aspek actus reus, dapat disikapi bersama mengingat indikator tindak pidana teroris terbatas pada tindakan spesifik yang tertuang dalam konvensi PBB, misalnya terjadinya pengeboman sehingga menciptakan kekhawatiran bagi masyarakat sekitar (Vincentia Wahju Widajatun, Nugi M. Nugraha, \& Sakina Ichsani, 2019).

\section{B. Tindak Pidana Teroris: Pengadilan Nasional dan Internasional}

Hubungan TIT dengan pengadilan nasional dan internasional dapat didasarkan pada prinsip keutamaan (menjalankan yurisdiksi hingga ke pengadilan) dan prinsip komplementaritas atau saling melengkapi (melimpahkan yurisdiksi kepada negara asal si pelaku) (Ignacio de la Rasilla, 2017).

\section{Prinsip Keutamaan}

Terdapat banyak kelebihan yang ditemukan pada pengadilan internasional yang berdasarkan prinsip keutamaan. Prinsip keutamaan ditemukan dalam beberapa pengadilan, di antaranya International Criminal Tribunal for the former Yugoslavia (ICTY) dan International Criminal Tribunal for Rwanda (ICTR), serta The Special Court for Sierra Leone (Andrey Sujatmoko, 2007). Lebih lanjut, Ken Gude (2006) menganjurkan untuk memasukkan tindak pidana teroris secara khusus di yurisdiksi internasional, dengan menyatakan bahwa:

"Apabila tahanan berasal dari sejumlah besar negara, dimana sering kali ditangkap di negara pihak kedua, bahkan mungkin oleh kekuatan negara pihak ketiga, masalah yurisdiksi bersamaan dan hubungan Pengadilan Khusus dengan Pengadilan Nasional harus jelas. Berdasarkan syarat-syarat perjanjian bilateral, Pengadilan Khusus harus memiliki keunggulan atas Pengadilan Nasional dan tidak seorangpun dapat diadili oleh pengadilan nasional untuk tindakan yang telah diadili oleh Pengadilan Khusus."

Adapun keunggulan dari pengadilan internasional, yang ditegaskan oleh Michael A. Newton (2001), bahwa:

"Pengadilan Internasional memiliki kebijaksanaan hukum yang tidak terbatas untuk memerintahkan Pengadilan Nasional untuk menunda Pengadilan Internasional 'pada setiap tahap persidangan',"

Salah satu alasan utama untuk memilih prinsip keutamaan adalah bahwa yurisdiksi nasional dinilai dibentuk untuk "melindungi” para tersangka. Dalam 
pengertian ini, ICTY mengekspresikan dirinya dalam kasus Tadic (Yogie Indra Kurniawan \& Ayub Torry Satrio Kusumo, 2016), bahwa:

\begin{abstract}
"Apabila Pengadilan Internasional dibentuk, maka harus memiliki kelebihan atas Pengadilan Nasional. Jika tidak, mengingat sifat manusia yang apa adanya, maka kejahatan internasional akan dicirikan sebagai 'kejahatan biasa', atau proses pengadilan 'dibentuk untuk melindungi para tersangka', atau 'kasus tidak dituntut sebagaimana mestinya'."
\end{abstract}

Berbeda halnya dalam kasus ICTR, dimana alasan utama untuk memilih prinsip keutamaan adalah, bahwa:

"Bukan karena yurisdiksi nasional dinilai melindungi para tersangka, melainkan karena Pengadilan Nasional dinilai kekurangan 'sumber daya material dasar untuk melakukan penyelidikan yang efektif'."

\title{
2. Prinsip Komplementaritas
}

MenurutJennifer Trahan (2012), prinsip komplementaritas hanya akan berjalan dengan baik jika pengadilan nasional bersedia dan mampu untuk menyelidiki hingga memberikan inkracht terhadap suatu kasus. Dengan demikian, Pengadilan Pidana Internasional hanya akan "melengkapi" investigasi dan penuntutan dari Pengadilan Nasional. Pengadilan Pidana Internasional akan mengambil alih suatu penyelesaian kasus tindak pidana apabila pengadilan nasional dinilai gagal dalam memutuskan suatu kasus.

Selanjutnya, terdapat tiga keutamaan dari sistem yuridiksi dan pengadilan dengan prinsip komplementaritas. Pertama, penghormatan terhadap kedaulatan negara dalam kaitannya dengan pelaksanaan ius puniendi, dimana menurut Neil Boister (2012) bahwa:

"Dengan tatanan non-hierarki horizontal, maka negara-negara akan lebih mudah untuk terlibat/bergabung bahkan meratifikasi yurisdiksi internasional."

Kedua, hubungan yang erat antara yurisdiksi nasional dengan yurisdiksi internasional, dimana menurut Jennifer Trahan (2012) bahwa:

"Dalam proses pengadilan pidana internasional harus dapat mengakhiri impunitas, dan pencegahan tindakan kejahatan serupa di masa mendatang."

Ketiga, kesadaran bahwa ruang lingkup tindakan pengadilan akan dibatasi karena alasan keterbatasan sumber daya, namun dalam aspek yang lebih praktis dapat menjadi dasar prinsip komplementaritas, dimana menurut Markus Benzing (2003), bahwa:

"Yurisdiksi/pengadilan nasional dapat menangani kasus dengan lebih efektif mengingat lebih dekat dengan bukti dan bahwa kejahatan di bawah yurisdiksi Pengadilan biasanya dituntut paling baik berdasarkan di negara mana kejahatan itu dilakukan."

Dari uraian di atas, TIT akan lebih mengedepankan prinsip komplementaritas apabila berada pada kondisi, yang sebagaimana diutarakan oleh Bogdan Aurescu \& Ion Gâlea (2015), bahwa: 
a. TIT harus memastikan kesiapan Pengadilan Nasional, dan hanya bertindak apabila terdapat kasus di mana negara yang berwenang tidak mau atau tidak dapat memberikan sanksi terhadap pelaku tindak pidana terorisme. Dengan cara demikian, TIT bertindak dalam rangka memperkuat kapasitas Pengadilan Nasional untuk memerangi tindak pidana terorisme;

b. Pengadilan Nasional harus melengkapi yurisdiksi terkait kasus-kasus tindak pidana terorisme sebagaimana yang akan ditetapkan dalam Pengadilan Pidana Internasional.

\section{Tindak Pidana Teroris: Legitimasi, Konsensus, serta Efektivitas Pengadilan Pidana Internasional}

Sebagaimana yang ditekankan oleh promotor atas pilihan ideal terkait TIT (Bogdan Aurescu \& Ion Gâlea, 2015), bahwa:

"Perjanjian internasional harus menyiratkan dasar hukum yang kuat dan koheren, dengan dukungan dan komitmen dari negara-negara di seluruh dunia."

Namun harus diakui bahwa memilih perjanjian internasional memilikitantangannya tersendiri dalam menghadapi ancaman yang terus berkembang seperti terorisme, sebagaimana yang telah terjadi atas kesepakatan pengadilan internasional lainnya, baik dalam proses ratifikasi hingga negosiasi untuk mengadopsi suatu undangundang. Adapun alternatif yang dikemukakan Dewan Keamanan Perserikatan Bangsa-Bangsa (DK PBB), bahwa "setiap tindakan terorisme internasional merupakan ancaman bagi perdamaian dan keamanan internasional" (Mamay Komariah, 2017). Oleh karena itu, sebagaimana yang dikemukakan oleh Richard J. Goldstone \& Janine Simpson (2003), bahwa:

"Pengadilaninternasionalakan memilikispesifikasitemporaldangeografis yang jelas serta terbatas. Sehingga, apabila penyelenggaraannya telah teraktualisasi dengan baik, maka pengadilan tersebut akan dibubarkan."

Kecepatan yang ditawarkan oleh resolusi DK PBB dalam perjanjian internasional secara teoritis telah membuat para promotor TIT memilih alternatif tersebut. Tidak dapat dipungkiri bahwa pengadilan Internasional sebagai alternatif perjanjian Internasional akan mempercepat proses negosiasi oleh negara-negara terkait, sebagaimana diungkapkan Bibi Van Ginkel (2009), bahwa:

"Alternatif ini hanya melibatkan 9 dari 15 anggota DK PBB dalam mengadopsi sebuah resolusi, namun serangkaian kebijakannya harus dihasilkan oleh analisis yang tajam. Selanjutnya, meskipun pihak yang bernegosiasi dalam proses pengadilan Internasional jauh lebih rendah daripada perjanjian internasional, tidak boleh dinafikan bahwa hak veto dari anggota tetap PBB dapat mempersoalkan keberadaan pengadilan Internasional tersebut."

\section{Tindak Pidana Teroris: Hambatan Hukum dalam Aspek Politik}

Dari pertemuan rapat ke-1, ke-2, ke-3, ke-4, ke-5, ke-28 dan ke-30, dari tanggal 2 sampai 4 Oktober dan pada tanggal 3 dan 10 November 2017, menghasilkan salah satu laporan dari komite bidang Hukum yang membahas tentang langkah-langkah pemberantasan tindak pidana terorisme internasional, menyatakan bahwa: 
"Delegasi merujuk pada peningkatan aktivitas terorisme dan menegaskan kembali pentingnya mencapai kesepakatan atas rancangan konvensi komprehensif tentang terorisme internasional dan perlunya mempercepat penyelesaian konsensus pada rancangan konvensi. Untuk tujuan ini, beberapa delegasi meminta semua Negara untuk menunjukkan kompromi dan fleksibilitas, karena penundaan yang tidak terbatas pada rancangan konvensi tidak dibenarkan. Ditekankan oleh beberapa delegasi bahwa definisi apa pun yang termasuk dalam rancangan konvensi harus membedakan tindak pidana terorisme dengan perjuangan sah rakyat dalam menjalankan hak mereka untuk menentukan nasib sendiri dari pendudukan asing atau dominasi kolonial."

Lebih lanjut, beberapa delegasi menilai, agar secara umum, rancangan konvensi harus memuat konsep terorisme negara, termasuk tindakan yang dilakukan oleh kekuatan militer suatu negara. Berkaitan dengan hal tersebut, disebutkan bahwa definisi terorisme harus mencakup aktivitas orang-orang yang menjadi komando angkatan bersenjata suatu Negara, atau yang mengendalikan kelompok bersenjata, dalam kasus-kasus di mana aktivitas tersebut tidak diatur oleh hukum humaniter internasional. Dilain sisi, terjadi kontroversi terkait pemberian kemerdekaan kepada Negara Kolonial dan Masyarakat yang diadopsi oleh Resolusi Majelis Umum PBB 1514 (XV), 14 desember 1960, sehingga dimulailah jalan untuk melegitimasi apa yang disebut "perang pembebasan nasional” (Inis L. Claude Jr., 1988).

Kontroversi politik seputar perbedaan antara kelompok pembebasan nasional dan kelompok teroris diringkas dengan ungkapan terkenal bahwa "satu orang pejuang kebebasan adalah teroris bagi orang lain" (Jelena Pejic, 2012). Terlepas dari konflik kepentingan dan variabel dari masing-masing Negara (Sami Zeidan, 2004), keberadaan tertentu menuju konsensus bersama tetaplah harus diprioritaskan.

\section{KESIMPULAN}

Berdasarkan uraian hasil dan pembahasan, maka dapat disimpulkan bahwa yurisdiksi dan pengadilan internasional tindak pidana terorisme dapat didasarkan pada prinsip keutamaan (menjalankan yurisdiksi hingga ke pengadilan) atau prinsip komplementaritas atau saling melengkapi (melimpahkan yurisdiksi kepada negara asal si pelaku). Selanjutnya, pengadilan internasional akan memiliki spesifikasi temporal dan geografis yang jelas dan terbatas, dan apabila penyelenggaraannya telah teraktualisasi dengan baik, maka pengadilan tersebut akan dibubarkan. Adapun beberapa anggota konvensi internasional menekankan bahwa definisi terkait tindak pidana terorisme harus jelas, khususnya dalam membedakan tindak pidana terorisme dengan perjuangan sah rakyat dalam menjalankan hak mereka untuk menentukan nasib sendiri dari pendudukan asing atau dominasi kolonial. Dengan dasar kesimpulan tersebut, untuk menghindari kontroversi politik, khususnya perihal konsep terorisme negara, maka disarankan agar memberikan definisi yang tepat atas tindak pidana terorisme dan diadopsi dalam yurisdiksi TIT untuk meminimalisir tindakan terorisme yang dapat terulang di masa yang akan datang. 


\section{REFERENSI}

Andrey Sujatmoko. (2007). Pengadilan Campuran ("Hybrid Tribunal") sebagai Forum Penyelesaian Atas Kejahatan Internasional.Jurnal Hukum Humaniter, Universitas Trisakti, 3(5), hlm. 970-985.

Ardli Johan Kusuma, et al. (2019). Analisis Perkembangan Norma Internasional "War on Terror" dalam Perspektif Realis, Liberalis dan Konstruktivis. Indonesian Perspective, Universitas Diponegoro, 4(1), hlm. 1-19.

Aryuni Yuliantiningsih. (2013). Perlindungan Pengungsi dalam Perspektif Hukum Internasional dan Hukum Islam (Studi terhadap Kasus Manusia Perahu Rohingya). Dinamika Hukum, Universitas Jenderal Soedirman, 13(1), hlm. 159170.

Association of Southeast Asian Nations Tahun 2007 tentang Asean Convention on Counter Terrorism. (Disahkan pada tanggal 17 Januari 2007, di Filipina).

Ben Saul. (2005). Attempts to Define 'Terrorism' in International Law. Netherlands International Law Review, 52(1), hlm. 57-83. doi: https://doi.org/10.1017/ S0165070X05000574

Bibi Van Ginkel. (2009). How to Repair the Legitimacy Deficit in the War in Terror: A Special Court for Dealing with International Terrorism? Dalam Challenges in a Changing World, diedit oleh Jaap de Zwaan, Edwin Bakker, \& Sico van der Meer, (hlm. 145-162). The Hague: Asser Press.

Bogdan Aurescu \& Ion Gâlea. (2015). Establishing an International Court against Terrorism. Constitutional Law Journal, Universul Juridic, 1(1), hlm. 105-116.

Council of the European Union Tahun 2015 tentang Outcome of the Council Meeting. (Diselenggarakan pada tanggal 9 Februari 2015, di Brussels).

Debora Sanur Lindawaty. (2016). Upaya Penanggulangan Terorisme ISIS di Indonesia. Jurnal Politica: Dinamika Masalah Politik Dalam Negeri dan Hubungan Internasional, Pusat Penelitian Badan Keahlian DPR RI, 7(1), hlm. 25-47.

Ignacio de la Rasilla. (2017). An International Terrorism Court in nuce in the Age of International Adjudication. Asian Yearbook of Human Rights and Humanitarian Law, 1, hlm. 76-108. doi: https://doi.org/10.1163/9789004339033_005

Imam Budi Santoso \& Taun Taun. (2018). Penerapan Asas Ultimum Remedium dalam Penegakan Hukum Pidana Lingkungan Hidup. University of Bengkulu Law Journal, Universitas Bengkulu, 3(1), hlm. 15-22. doi: https://doi.org/10.33369/ ubelaj.3.1.15-22

Inis L. Claude Jr. (1988). States and the Global System: Politics, Law and Organization. London: Palgrave Macmillan.

Jelena Pejic. (2012). Armed Conflict and Terrorism: There is a (Big) Difference. Dalam Counter-Terrorism: International Law and Practice, diedit oleh Ana Maria Salinas de Frias, Katja L. H. Samuel, \& Nigel D. White, (hlm. 171-204). Oxford: Oxford University Press. 
Jennifer Trahan. (2012). Is Complementarity the Right Approach for the International Criminal Court's Crime of Aggression - Considering the Problem of Overzealous National Court Prosecutions. Cornell International Law Journal, 45(3), hlm. 569-601.

Ken Gude. (2006). After Guantanamo: A Special Tribunal for International Terrorist Suspects. Washington D.C.: Center for American Progress.

League of Nations Tahun 1937 tentang Convention for the Prevention and Punishment of Terrorism. (Disahkan pada tanggal 16 November 1937, di Geneva).

M. Cherif Bassiouni. (1974). Methodological Options for International Legal Control of Terrorism. Akron Law Review, The University of Akron, 7(3), hlm. 388-396.

Mamay Komariah. (2017). Kajian Tindak Pidana Terorisme dalam Perspektif Hukum Pidana Internasional. Jurnal Ilmiah Galuh Justisi, Universitas Galuh, 5(1-23) doi: http://dx.doi.org/10.25157/jigj.v5i1.281

Markus Benzing. (2003). The Complementarity Regime of the International Criminal Court: International Criminal Justice between State Sovereignty and the Fight against Impunity. Max Planck Yearbook of United Nations Law, 7(1), hlm. 591632. doi: https://doi.org/10.1163/187574103X00112

Masdar Hilmy. (2015). Radikalisme Agama dan Politik Demokrasi di Indonesia PascaOrde Baru. Miqot: Jurnal Ilmu-ilmu Keislaman, Universitas Islam Negeri Sumatera Utara, 39(2), hlm. 407-425. doi: http://dx.doi.org/10.30821/miqot.v39i2.33

Michael A. Newton. (2001). Comparative Complementarity: Domestic Jurisdiction Consistent with the Rome Statute of the International Criminal Court. Military Law Review, 167, hlm. 20-73.

Muh. Khamdan. (2016). Pengembangan Bina Damai dalam Penanganan Tindak Pidana Terorisme di Indonesia. Jurnal Cita Hukum, UIN Syarif Hidayatullah Jakarta, 4(1), hlm. 105-132. doi: http://dx.doi.org/10.15408/jch.v4i1.2835

Neil Boister. (2012). International Tribunals for Transnational Crimes: Towards a Transnational Criminal Court? Criminal Law Forum, 23, hlm. 295-318. doi: https://doi.org/10.1007/s10609-012-9182-4

Nurul Qamar \& Farah Syah Rezah. (2020). Metode Penelitian Hukum: Doktrinal dan Non-Doktrinal. Makassar: CV. Social Politic Genius (SIGn).

Peraturan Presiden Republik Indonesia Nomor 3 Tahun 2010 tentang Pengesahan Memorandum Saling Pengertian antara Pemerintah Republik Indonesia dan Pemerintah Federasi Rusia tentang Kerja Sama di Bidang Pemberantasan Terorisme (Memorandum of Understanding Between the Government of the Republic of Indonesia and the Government of the Russian Federation on Cooperation in Combating Terrorism). (Lembaran Negara Republik Indonesia Tahun 2010 Nomor 3).

Peter Mahmud Marzuki. (2016). Penelitian Hukum. Jakarta: Kencana Prenada Media Group.

Rahmat Hi. Abdullah. (2015). Urgensi Hukum Adat dalam Pembaharuan Hukum Pidana Nasional. Fiat Justisia: Jurnal Ilmu Hukum, Universitas Lampung, 9(2), hlm. 168-181. doi: https://doi.org/10.25041/fiatjustisia.v9no2.595 
Richard J. Goldstone \& Janine Simpson. (2003). Evaluating the Role of the International Criminal Court as a Legal Response to Terrorism. Harvard Human Rights Journal, 16, hlm. 13-26.

Robert Cryer, Darryl Robinson, \& Sergey Vasiliev. (2019). Transnational Crimes, Terrorism and Torture. Dalam An Introduction to International Criminal Law and Procedure, (Edisi 4 hlm. 319-340). Cambridge: Cambridge University Press.

Said Sampara \& La Ode Husen. (2016). Metode Penelitian Hukum. Makassar: Kretakupa Print.

Sami Zeidan. (2004). Desperately Seeking Definition: The International Community's Quest for Identifying the Specter of Terrorism. Cornell International Law Journal, 36(3), hlm. 491 - 496.

Syarif Saddam Rivanie. (2020). "Deradikalisasi sebagai Sanksi dalam Pemberantasan Tindak Pidana Terorisme”. Disertasi. Universitas Airlangga, Surabaya.

Umbu Lily Pakuwali. (2009). Revitaliasasi Supremasi Hukum dalam Mengatasi Krisis Hukum. Pro Justitia, Universitas Katolik Parahyangan, 27(1), hlm. 99-112.

Undang-Undang Republik Indonesia Nomor 5 Tahun 2006 tentang Pengesahan International Conventional for the Suppression of Terrorist Bombings, 1997 (Konvensi Internasional Pemberantasan Pengeboman oleh Teroris, 1997). (Lembaran Negara Republik Indonesia Tahun 2006 Nomor 28. Tambahan Lembaran Negara Republik Indonesia Nomor 4616).

Undang-Undang Republik Indonesia Nomor 6 Tahun 2006 tentang Pengesahan International Convention for the Suppression of the Financing of Terrorism, 1999 (Konvensi Internasional Pemberantasan Pendanaan Terorisme, 1999). (Lembaran Negara Republik Indonesia Tahun 2006 Nomor 29. Tambahan Lembaran Negara Republik Indonesia Nomor 4617).

Undang-Undang Republik Indonesia Nomor 5 Tahun 2012 tentang Pengesahan Asean Convention on Counter Terrorism (Konvensi Asean Mengenai Pemberantasan Terorisme). (Lembaran Negara Republik Indonesia Tahun 2012 Nomor 93. Tambahan Lembaran Negara Republik Indonesia Nomor 5306).

Undang-Undang Republik Indonesia Nomor 10 Tahun 2014 tentang Pengesahan International Convention for the Suppression of Acts of Nuclear Terrorism (Konvensi Internasional Penanggulangan Tindakan Terorisme Nuklir). (Lembaran Negara Republik Indonesia Tahun 2014 Nomor 59. Tambahan Lembaran Negara Republik Indonesia Nomor 5518).

United Nations Security Council Counter-Terrorism Committee Tahun 2015 tentang Stemming the Flow of Foreign Terrorist Fighters. (Diselenggarakan pada tanggal 28 Juli 2015, di Madrid).

United Nations Tahun 1993 tentang International Criminal Tribunal for the former Yugoslavia. (Disahkan pada tanggal 25 Mei 1993, di Den Haag).

United Nations Tahun 1994 tentang International Criminal Tribunal for Rwanda. (Disahkan pada tanggal 8 November 1994, di Tanzania). 
United Nations Tahun 1997 tentang International Convention for the Suppression of Terrorist Bombings. (Disahkan pada tanggal 12 Januari 1998, di New York).

United Nations Tahun 1998 tentang Rome Statute of the International Criminal Court. (Disahkan pada tanggal 17 Juli 1998, di Roma).

United Nations Tahun 1999 tentang International Convention for the Suppression of the Financing of Terrorism. (Disahkan pada tanggal 10 Januari 2000, di New York).

United Nations Tahun 2000 tentang United Nations Convention against Transnational Organized Crime. (Disahkan pada tanggal 12 Desember 2000, di Palermo).

United Nations Tahun 2005 tentang International Convention for the Suppression of Acts of Nuclear Terrorism. (Disahkan pada tanggal 14 September 2005, di New York).

Vincentia Wahju Widajatun, Nugi M. Nugraha, \& Sakina Ichsani. (2019). Kejadian Aksi Teroris dan Dampaknya pada Performa Nilai Tukar Dolar Amerika Serikat dan Performa IHSG. Jurnal Muara: Ilmu Ekonomi dan Bisnis, Universitas Tarumanagara, 3(1), hlm. 141-155. doi: http://dx.doi.org/10.24912/jmieb. v3i1.3415

Yogie Indra Kurniawan \& Ayub Torry Satrio Kusumo. (2016). Yurisdiksi the Mechanism for International Criminal Tribunals (MICT) terhadap Kejahatan HAM Berat yang Dilakukan Ratko Mladić pada saat Konflik Bersenjata di Bosnia-Herzegovina. Belli Ac Pacis: Jurnal Hukum Internasional, Universitas Sebelas Maret, 2(2), hlm. 23-31.

I Syarif Saddam Rivanie. (2020). Pengadilan Internasional dalam Memberantas Tindak I

Pidana Terorisme: Tantangan Hukum dan Politik. Sovereign: Jurnal Ilmiah Hukum, CV. I I Social Politic Genius (SIGn), 2(3), hlm. 15-27. doi: https://doi.org/10.37276/sjih.v2i3.36 I

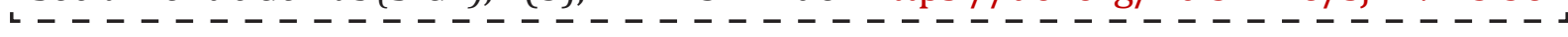

